\title{
Penyuluhan dan Pembuatan Pupuk Organik yang Prospektif
}

\author{
Elly Istiana Maulida ${ }^{1)}$, Priyono ${ }^{2)}$ \\ ${ }^{112)}$ Universitas Salmet Riyadi, Surakarta, Indonesia \\ Corresponding author: Elly Istiana Maulida, elly.istiana.maulida@unisri.ac.id
}

\begin{abstract}
Abstrak: Sampah di Indonesia terdiri dari $70 \%$ sampah hayati $28 \%$ sampah non hayati dan $2 \%$ sampah B3 (bahan beracun). Dalam pengelolaan sampah perlu mendayagunakan keterpaduan antara lembaga dan masyarakat yang ada di desa maupun fihak lain yang terkait sehingga perlu sekali adanya suatu perencanaan yang matang dan terkendali. Oleh karena itu Fakultas Pertanian UNISRI mengadakan pengabdian masyarakat dengan kelompok tani "Wijaya Kusuma" di desa Geneng, Kecamatan Gatak, Kabupaten Sukoharjo dengan tujuan memberikan pengetahuan penting secara komprehensip kepada masyarakat menyangkut teknis maupun pengelolaan bahan organik dari limbah pertanian dan rumah tangga menjadi pupuk organik yang prospektif dengan model bank sampah yang dapat digunakan sebagai upaya mitigasi kerusakan tanah pada khususnya serta meningkatkan pendapatan masyarakat pada umumnya. Sistem pengelolaan sampah model perbankan yaitu dengan pemisahan sampah organik dan anorganik agar efisien dan efektif dalam pembuatan pupuk organik. Dalam kegiatan pengabdian ini, peserta sangat antusias mengikuti kegiatan mulai dari penyuluhan (banyak peserta yang bertanya) sampai dengan demonstrasi (semua peserta ikut langsung mempraktekkan) pembuatan pupuk organik dari limbah pertanian dan limbah rumah tangga.
\end{abstract}

Kata Kunci : Bank sampah, pupuk organik dan mitigasi

\begin{abstract}
Waste in Indonesia consists of 70\% biological waste, 28\% non-biological waste and 2\% B3 waste (toxic materials). In waste management, it is necessary to make use of the integration between institutions and communities in the village and other related parties, so it is necessary to have a careful and controlled planning. Therefore, the Faculty of Agriculture UNISRI held community service with the farmer group "Wijaya Kusuma" in Geneng Village, Gatak District, Sukoharjo Regency with the aim of providing important comprehensive knowledge to the community regarding technical and management of organic materials from agricultural and household waste into organic fertilizers which prospective with a waste bank model that can be used as an effort to mitigate land damage in particular and increase community income in general. The banking model waste management system is the separation of organic and inorganic waste to make it efficient and effective in making organic fertilizers. In this service activity, participants were very enthusiastic about participating in activities ranging from counseling (many participants asked) to demonstrations (all participants directly practiced) making organic fertilizers from agricultural waste and household waste.
\end{abstract}

Keywords : Waste bank, organic fertilizer, mitigation

\section{Pendahuluan}

Kecamatan Gatak merupakan bagian dari wilayah Kabupaten Sukoharjo yang mempunyai luas $19,45 \mathrm{~km}^{2}$ dan dihuni oleh 44.220 jiwa dengan kepadatan penduduk rata-rata 
$227 \mathrm{jiwa} / \mathrm{km}^{2}$. Di kecamatan ini terdapat 14 desa dan salah satunya adalah desa Geneng. Desa Geneng mempunyai luas wilayah $1,43 \mathrm{~km}^{2}$ dengan jumlah penduduk berdasarkan data BPSB Sukoharjo tahun 2013 dan tahun 2017 masing-masing 3593 jiwa dan 3651 jiwa. Menurut Sukroraharjo (2018) perubahan bentuk penggunaan lahan di desa Geneng sangat tinggi, hal ini disebabkan oleh pertambahan penduduk yang tinggi.

Sementara mata pencaharian penduduk disini sebagian besar bertani dan berdagang yang merupakan warisan dari nenek moyang-nya (turun-temurun) sehinga hasilnya belum optimal. Tingkat pendidikan masyarakat di desa Geneng juga masih rendah (SLTP). Sebagian besar para pemudanya bekerja sebagi karyawan pabrik/toko dan kuli bangunan terutama di daerah karesidenan Surakarta dan sebagian migran/marantau ke kota-kota besar di Indonesia. Sebagian lagi masyarakat bekerja sebagai peternak dan PNS/ABRI/ guru, serta sebagaian lagi banyak sekali diusia sekolah/kursus dan sebagian besar yang bersekolah TK, SD, SLTP dan SLTA, sebagian kecil melanjutkan kuliha ke PTS/PTN.

Jika disimak, di desa Geneng dari fenomena tersebut minimal dapat ditarik permasalan pokok yang cukup krusial dan harus cepat ditangani:

1. Pertumbuhan penduduk yang pesat dan semakin sempitnya lahan pertanian

2. Banyak lahan pertanian dijual dengan harga relatif murah kepada orang luar dan dijadikan untuk industri yang tidak padat karya.

3. Hasil pertanian (padi) yang di kelola kebanyakan masyarakat setempat selama ini tidak bisa menjamin kehidupan ekonominya akibat harga yang telalu rendah dan pemasaran kurang.

4. Pengelolaan pekarangan kebanyakan masyarakat di daerah tersebut belum intensif (bukan bibit unggul, hasil masih rendah, tidak menunjang ekonomi dll).

5. Usaha peternakan lembu dan ayam yang masih tradisional (makanannya berupa rumput/hijau daun yang ada disekitarnya, usaha home industri yang tidak kontinyu dll)

6. Sebagian besar para pemudanya banyak yang meningaglkan rumah (urbanisasi mencari pekerjaan ke tempat lain yang dianggap yang lebih menjanjikan).

7. Pengelolaan lahan pertanian, peternakan, perikanan, home industri lebih banyak dikerjakan oleh orang yang usiannya sudah kelapa 45 keatas, dengan upah rendah, pendidikan rendah sehingga hasil kerjanya belum berjalan optimal dan kurang profesional.

Pada tahun 2011, Maulida melakukan penelitian terhadap pupuk kandang yang diaplikasikan pada beras merah varietas Anon dan hasilnya mampu meningkatkan berat gabah 1000 biji sebesar 25\% karena kandungan bahan organik pada pupuk kandang yang tinggi selain cepat melepaskan unsur hara juga meningkatkan kemantapan agregat tanah, mengingkatkan kapasitas menahan air, serta dapat meningkatkan kapasitas tukar kation yang dibutuhkan oleh tanaman. Menurut Sugiyanta dan Aziz (2016), konsep dasar pertanian organik adalah cara produksi tanaman dengan menghindarkan atau sebesar-besarnya mencegah penggunaan senyawa-senyawa kimia sintetik (pupuk, pestisida dan zat pengatur tumbuh). Berdasarkan permasalahan di desa Geneng, serta pengalaman saya dalam pupuk kandang, maka yang harus dilakukan untuk meningkatkan perekonomian masyarakat setempat yaitu melihat potensi kemampuan yang dapat diangkat dan dikembangkan, disamping memperhatikan ketrampilan serta kondisinya sehingga yang paling mungkin dikembangkan adalah sistem pertanian organik terutama penggunaan dan produksi pupuk organik dari limbah pertanian maupun limbah rumah tangga. Langkah yang harus dilakukan pertama untuk meningkatkat perekonomian masyarakat desa Geneng adalah mengadakan penyuluhan untuk memotivasi dan memberikan pengetahuan secara luas serta komprehensip kepada masyarakat menyangkut teknis maupun pengelolaan bahan organik dengan model bank sampah yang dapat digunakan untuk upaya mitigasi 
kerusakan tanah maupun pertumbuhan dan hasil tanaman serta upaya pelestarian lingkungan untuk kesejahteraan rakyat. Peran bank sampah menjadi penting dengan terbitnya Peraturan Pemerintah (PP) Nomor 81 Tahun 2012 tentang pengolahan sampah rumah tangga dan sampah sejenis sampah rumah tangga (Suryani, 2014). Keunikan dari bank sampah dalam pengabdian ini salah satunya sampah dari limbah pertanian mina padi karena kelompok tani Wijaya Kusuma sudah menerapkan mina padi. Menurut Kementrian Kelautan dan Perikanan Republik Indonesai (2016) budidaya mina padi adalah budidaya ikan dan padi dalam satu hamparan sawah. Dengan adanya pemeliharaan ikan di persawahan tersebut, banyak keuntungan yang didapat antara lain meningkatkan pendapatan petani dengan penjualan ikan. Meningkatkan kesuburan tanah karena korotan ikan bisa dijadikan pupuk organik sehingga mengurangi penggunaan pupuk anorganik. Menekan atau mengurangi penggunaan pestisida kimia karena ikan memakan tumbuhan kecil (gulma) yang tumbuh disekitar tanaman padi sehingga persaingan antara padi dan gulma dalam menyerap nutrisi dapat dikurangi. Selain itu, ikan juga memakan binatang - binatang kecil yang merupakan hama padi (Lestari dan Bambang, 2017). Jadi limbah pertanian di bank sampah yang dikelola kelompok tani Wijaya Kusuma merupakan limbah organik tanpa ada zat kimia sama sekali. Tujuan dari kegiatan pengabdian masyarakat ini yaitu mengoptimalkan lahan pertanian yang sempit dengan sistem bank sampah untuk diolah mejadi pupuk oganik sehingga dapat meningkatkan pendapatan masyarakat di desa Geneng pada khususnya dan upaya mitigasi kerusakan tanah pada umumnya.

\section{Metodologi}

Pengabdian ini dilaksanakan di rumah bapak Suwanto ketua Rw desa Geneng, Kecamatan Gatak, Kabupaten Sukoharjo pada hari sabtu tanggal 07 September 2020 pukul 09.00 sampai 12.00 WIB untuk penyuluhan dan tanggal 12 September 2020 untuk demontrasi. Pengabdian ini diikuti kurang lebih sekitar 20 orang (bapak dan ibu) dari anggota kelompok tani "Wijaya Kusuma" desa Geneng. Metode pengabdian yang digunakan saat penyuluhan adalah ceramah, demonstrasi/orientasi lapang dan monitoring. Materi ceramah penyuluhan meliputi cara mengidentifikasi dan memisahkan sampah organik dan anorganik dengan bank sampah dan cara pembuatan pupuk organik dari limbah pertanian dan rumah tangga. Untuk sampah organik masih dipisahkan menjadi limbah pertanian mina padi dan sampah organik dari rumah tangga.

Demontrasi lapangan dimulai dari menyiapkan alat (botol air mineral ukuran 1 liter, selang, blender, saringan, pengaduk) dan bahan (sampah organik dari limbah pertanian mina padi dan rumah tangga, air, gula merah/gula pasir/kecap/EM4), cara pembuatan pupuk organik yaitu bahan yang sudah dipilah atau dipisah masing - masing dicampur dengan air dihaluskan menggunakan blender dengan perbandingan 2 liter air untuk $1 \mathrm{~kg}$ bahan. Kemudian disaring menggunakan saringan. Setelah disaring, air saringan dimasukkan kedalam botol air mineral. Tambahkan gula pasir/gula merah/kecap/EM 4 untuk membantu proses mempercepat pengomposan. Tutup botol dengan tutup yang sudah dilubangi dan dimasukkan selang. Kemudian dihubungkan dengan tutup botol air mineral yang satunya dimana botol sudah diisi dengan air tujuannya untuk mendinginkan saat proses pengomposan. Menurut Susanto (2002), selama proses pengoposan berlangsung akan terjadi reaksi eksotermik sehingga timbul panas akibat pelepasan energi. Proses pengomposan biasanya berlangsung selama kurang lebih 3 minggu. Pengomposan berakhir ditandai dengan nilai $\mathrm{C} / \mathrm{N}$ rasio kompos yang semakin rendah yaitu < 20 (Ismayana et al., 2012). Monitoring dilakukan saat proses pengomposan berlangsung dan pada tanaman yang sudah diaplikasikan pupuk. Monitoring pupuk dilakukan setiap 1 minggu sekali (selama hampir 3 minggu untuk proses pengomposan dan 1 bulan untuk 
monitoring tanaman). Monitoring dilakukan dengan tujuan apabila ada permasalahan di lapang bisa langsung teratasi.

\section{Hasil dan Pembahasan}

A. Penyuluhan Tentang Pembuatan Pupuk Organik yang Prospektif

Penyuluhan dilakukan dengan metode ceramah dan tanya jawab yang dilaksanakan pada tanggal 07 September 2020 pukul 09.00 WIB sampai 12.00 WIB. Materi penyuluhan dimulai dari penjelasan pemisahan sampah anorganik dan sampah organik. Sampah organik dipilah lagi menjadi limbah pertanian mina padi dan limbah rumah tangga. Kemudian cara pembuatan pupuk organik mulai dari persiapan alat dan bahan sampai proses pengomposan berakhir. Selesai penyuluhan, bapak ibu yang hadir mulai mengaplikasikan ilmu yang didapat dengan dimulai memisahkan sampah organik dan anorganik (bank sampah) sekitar 1 minggu. Kemudian tanggal 12 September 2020 mulai demonstrasi pembuatan pupuk organik dari limbah rumah tangga yang sudah terkumpul selama 1 minggu.

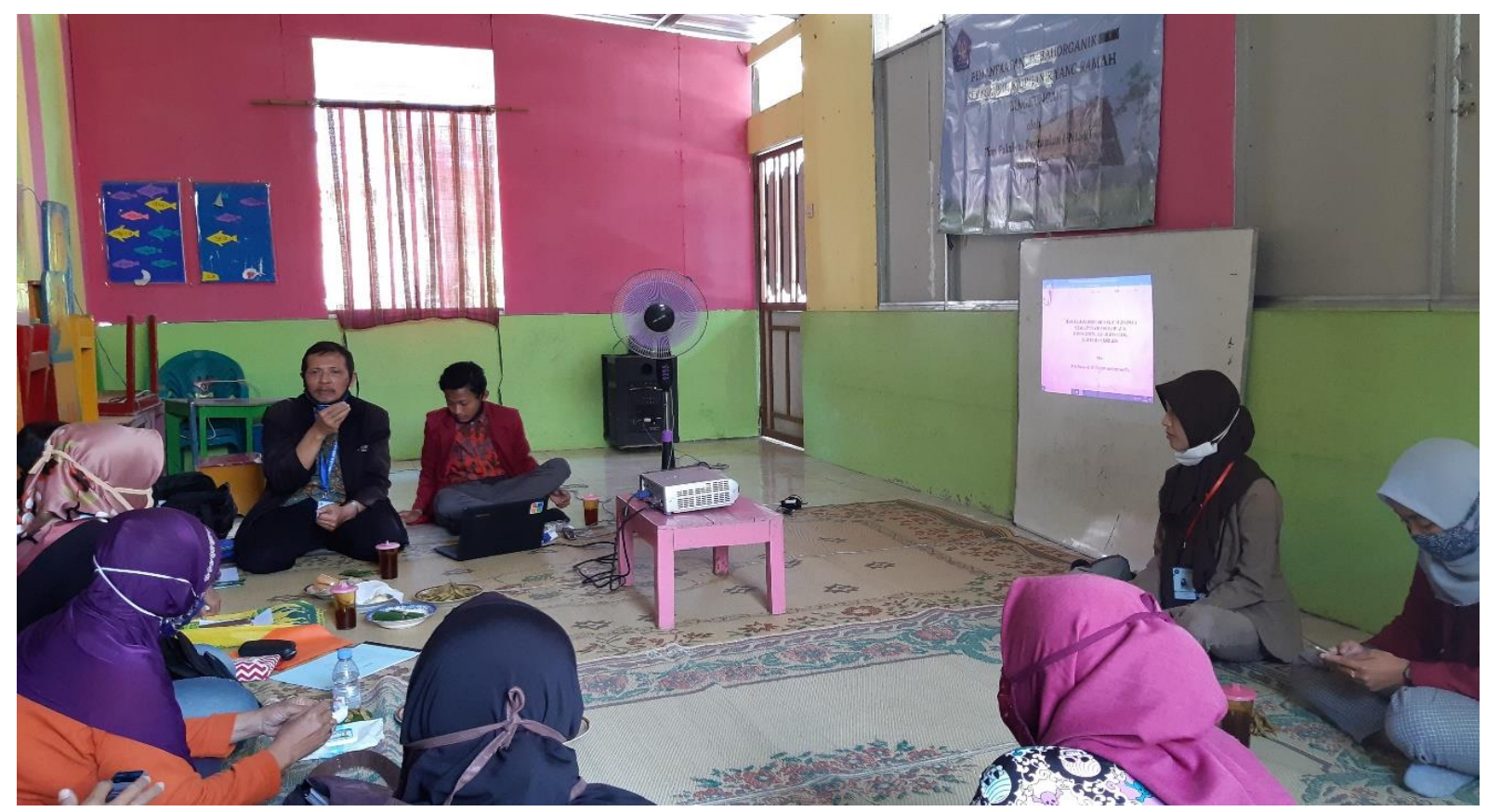

Gambar 1. Kegiatan Penyuluhan

(Penyuluhan dilaksanakan pada saat pandemi covid 19 dengan menerapkan protokol kesehatan)

B. Demonstrasi dan Pendampingan Cara Pembuatan Pupuk Organik yang Prespektif

1. Cara membuat pupuk organik cair

Menyiapkan alat : 2 botol air mineral ukuran 1 liter, selang, blender, pengaduk, saringan. Bahan : sampah rumah tangga yang sudah dipisahkan organik dan anorganik selama 1 minggu karena yang akan digunakan sampah organik, larutan gula, EM 4, air. Cara pembuatan pupuknya 1 . Potong menjadi bagian - bagian kecil sampah organik baik dari limbah pertanian mina padi maupun dari limbah rumah tangga secara terpisah (menggunakan blender yang dicampur air), 2. Saring limbah organik yang sudah diblender, 3. masukkan air hasil saringan kedalam botol air mineral yang tutupnya sudah dilubangi dan dikasih selang, 4. Tambahkan larutan gula dan EM 4 kedalam botol yang sudah berisi limbah organik cair, 5. Tutup botol dan hubungkan dengan botol yang satunya yang sudah diisi air dengan selang. 6. Diamkan selama 
kurang lebih 3 minggu sambil dimonitoring proses pengomposannya (indikator proses pengomposan berhasil apabila nilai $\mathrm{C} / \mathrm{N}$ rasionya $<20$ dan sudah tidak tercium bau seperti belerang). Pupuk organik cair jadi, pupuk diaplikasikan ke tanah dengan harapan mampu meningkatkan meningkatkan produktifitas komoditas pertanian kedepannya. Menurut Zahroh et al (2018), pupuk organik cair mengandung unsur hara makro dan mikro esensial yang cukup tinggi seperti N, P, K, S, Ca, Mg, B, Mo, Cu, Fe, Mn, dan bahan organik Sisa perasan limbah organik juga bisa dijadikan pupuk dengan cara mencampurkan dengan tanah sebagai media tanam.

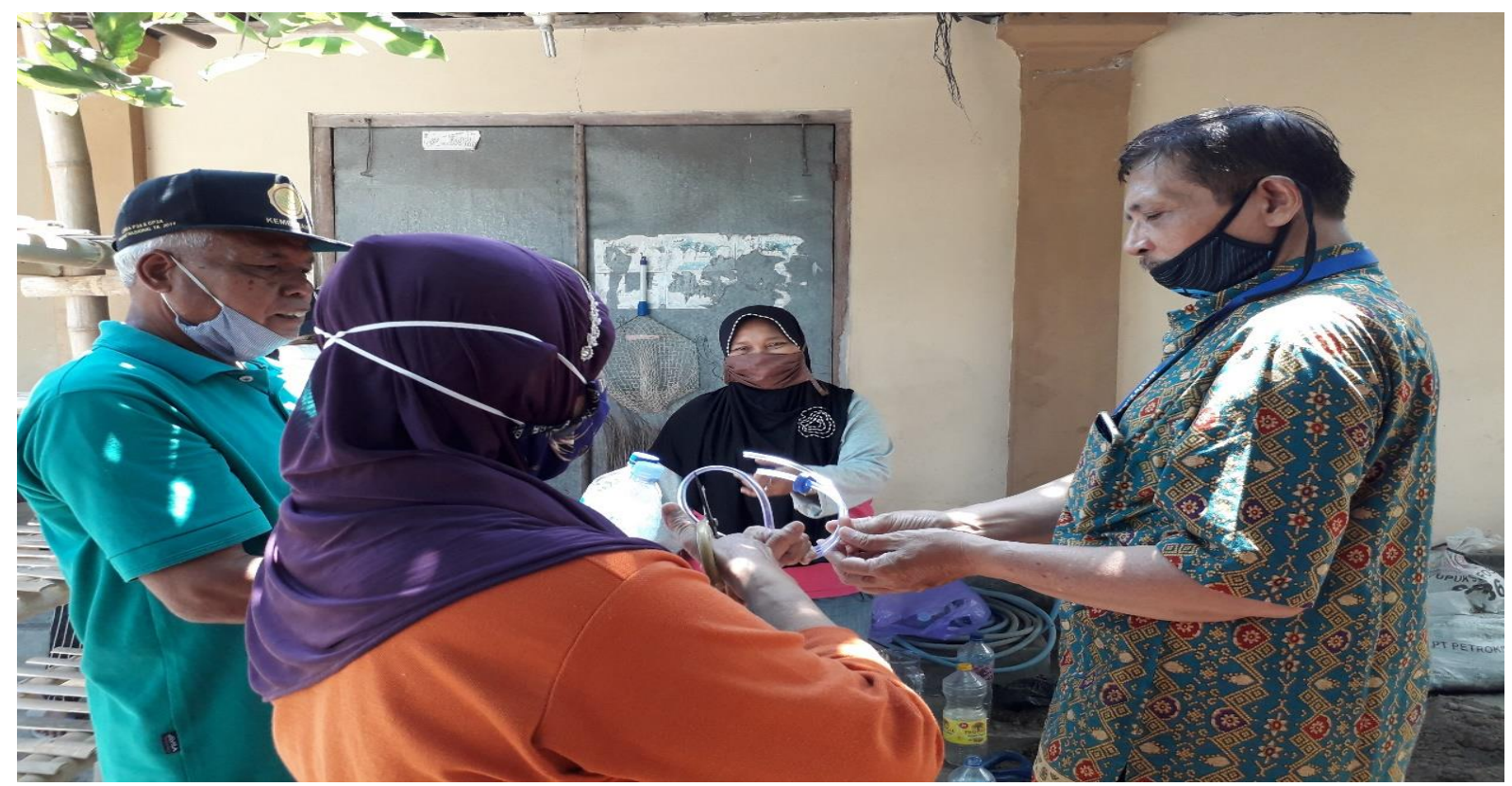

Gambar 2. Memasang Selang Ke Botol Air Mineral

(demonstrasi dilaksanakan pada saat pandemi covid 19 dengan menerapkan protokol kesehatan)

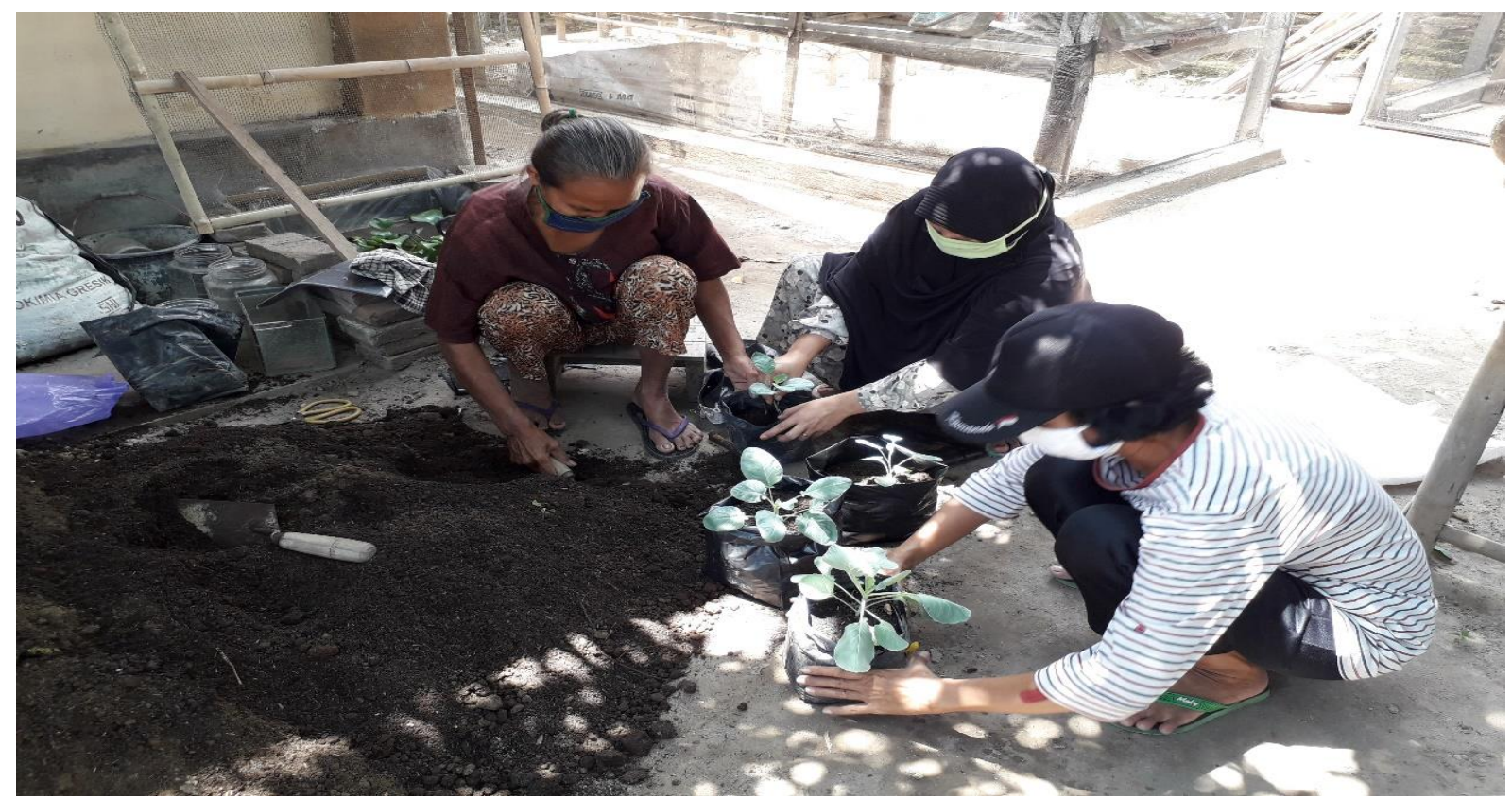

Gambar 3. Ampas Sampah Organik Yang Dicampur Dengan Tanah Dan Pupuk Organik Sebagai Media Tanam (demonstrasi dilaksanakan pada saat pandemi covid 19 dengan menerapkan protokol kesehatan) 


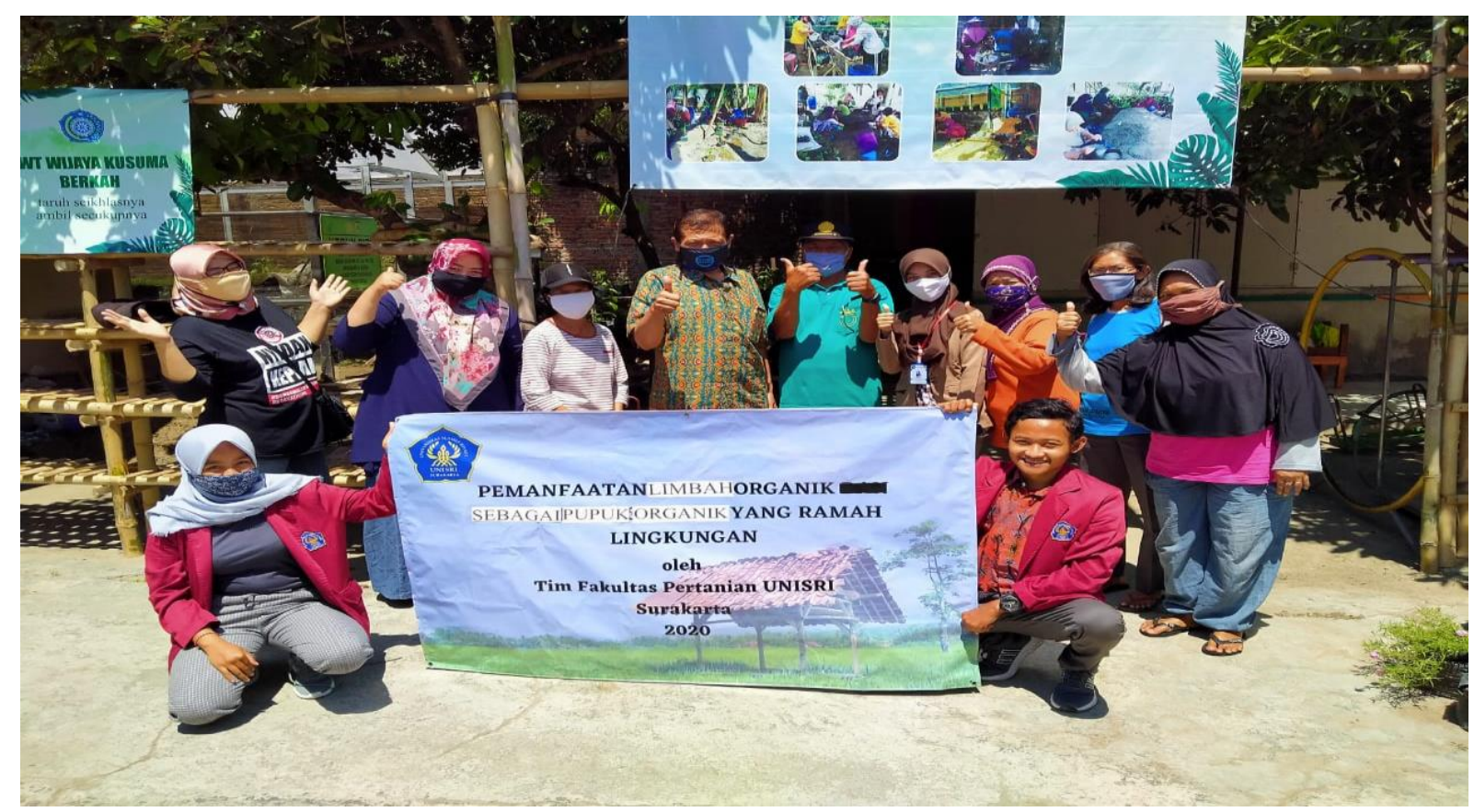

Gambar 4. Foto Bersama Pengurus Kelompok Tani Wijaya Kusuma Desa Geneng

(Foto Bersama dilaksanakan pada saat pandemi covid 19 dengan menerapkan protokol kesehatan).

\section{Faktor pendukung}

Adapun faktor pendukung kegiatan ini adalah 1) Sebagian besar masyarakat desa Geneng bapak-bapaknya berprofesi sebagai petani atau pedagang dan ibu-ibunya sebagai ibu rumah tangga, 2) Bahan lokal yang digunakan untuk pembuatan pupuk organik adalah limbah atau sisa tanaman pertanian mina padi dan limbah sisa memasak yang organik 3) Bahan lain yang ditambahkan untuk pembuatan pupuk organik adalah bahan yang membantu mempercepat proses pembuatan pupuk seperti EM 4/gula pasir/gula jawa/kecap.

\section{Faktor Penghambat}

Faktor Penghambat antara lain 1) bapak-bapak dan ibu-ibu kelompok tani yang hadir didominasi usia lanjut sehingga cenderung kurang mampu mengikuti kemajuan teknologi pembuatan pupuk organik, 2) masyarakat masih belum terbiasa bahkan terkadang lupa untuk memisahkan limbah organik dan anorganik. Terutama untuk memisahkan limbah yang dari pertanian mina padi dengan limbah dari rumah tangga yang organik.

\section{Partisipasi masyarakat}

Bentuk partisipasi peserta dapat dilihat dari kehadiran anggota kelompok tani Wijaya Kusuma yang bersedia meluangkan waktu di tengah-tengah kesibukanya hadir di rumah bapak Suwanto. Antusias para masyarakat yang tergabung dalam kelompok tani Wijaya Kusuma sangat tinggi hal ini bisa dilihat dari banyaknya peserta penyuluhan yang bertanya dan ikut langsung dalam praktek pembuatan pupuk organik yang prespektif.

5. Indikator keberhasilan dari pengabdian masyarakat dan hasil yang di capai.

Hasil yang dicapai dalam pengabdian masyarakat ini adalah para masyarakat yang tergabung dalam kelompok tani Wijaya Kusuma memiliki tambahan pengetahuan dan mampu mengolah limbah organik dari limbah pertanian mina padi dan limbah rumah tangga menjadi pupuk organik mulai dari pemisahan sampah organik dan anorganik ke bank sampah, 
menyiapkan alat dan bahan, cara membuat pupuk organik, monitoring proses pengoposan (pengoposan berhasil dintandai denga nilai $\mathrm{C} / \mathrm{N}$ rasio $<20$ dan sudah tidak tercium bau seperti belerang). Pupuk organik cair yang sudah berhasil dibuat diaplikasikan ke tanaman (khususnya) dan nantinya akan diproduksi dalam jumlah besar untuk dijual (umumnya) sehingga mampu menghemat pengeluaran untuk pembelian pupuk, hasil produksi pertanian meningkat. Selain itu, pengetahuan yang diberikan tentang pupuk organik dan cara pembuatannya dapat meningkatkan kesadaran masyarakat desa Geneng mengenai pentingnya menjaga kebersihan lingkungan.

Di akhir kegiatan pengabdian masyarakat, kami memberikan bantaun 5 karung pupuk kandang kepada kelompok tani Wijaya Kusuma untuk diberikan ke tanah dengan harapan dapat memperbaiki kesuburan tanah sekaligus menyediakan unsur hara yang dibutuhkan oleh tanaman. Sebagai simbolis kami membuka 1 karung pupuk untuk dicampurkan dengan tanah sebagai media tanam dengan perbandingan kompos dan tanah $1: 1$ (Hayati et al., 2012).

\section{Simpulan}

Dari kegiatan pengabdian masyarakat ini, masyarakat desa Geneng terutama yang tergabung dalam kelompok tani Wijaya Kusuma mampu mengolah limbah pertanian mina padi dan limbah rumah tangga menjadi pupuk organik yang prospektif. Indikator keberhasilan dari pembuatan pupuk organik apabila nilai $\mathrm{C} / \mathrm{N}$ rasio pupuk organik $<20$ dan sudah tidak tercium seterti belerang.

\section{Ucapan Terima Kasih}

Dengan segala kerendahan hati, penulis mengucapkan terima kasih kepada Ketua Yayasan Universitas Slamet Riyadi Surakarta yang sudah membantu pembiayaan dalam kegiatan Pengabdian Masyarakat. LPPM yang sudah memfasilitasi kegiatan Pengabdian Masyarakat. Dekan Fakultas Pertanian Dr. Dewi Ratna Nurhayati, MP yang sudah membantu administrasi untuk kelancaran kegiatan Pengabdian Masyarakat. Rekan Dosen satu tim Pengabdian Masyarakat Dr. Priyono, SE., SH., MM yang membantu memberikan penyuluhan, demonstrasi dan monitoring pembuatan pupuk organik dari limbah pertanian dan rumah tangga. Ketua Rw desa Geneng bapak Suwanto, yang telah mengijinkan rumah tinggalnya untuk digunakan sebagai tempat penyuluhan dan demonstrasi pembuatan pupuk organik dari limbah pertanian dan rumah tangga. Kelompok tani Wijaya Kusuma desa Geneng yang telah meluangkan waktu untuk mengikuti kegiatan penyuluhan, demontrasi dan monitoring pembuatan pupuk organik dari limbah rumah pertanian dan rumah tangga.

\section{Daftar Pustaka}

Badan Pusat Statistik. 2013. Kecamatan Gatak Dalam Angka. Sukoharjo. Badan Pusat Statistik. Badan Pusat Statistik. 2017. Kecamatan Gatak Dalam Angka. Sukoharjo. Badan Pusat Statistik. Hayati, E., T. Mahmud dan R. Fazil. 2012. Pengaruh Jenis Pupuk Organik dan Varietas Terhadap Pertumbuhan dan Hasil Tanaman Cabai (Capsicum annum L.). Jurnal Floratek Vol $7: 173-181$.

Ismayana, A., N. S. Indrasti., Suprihatin., A. Maddu dan A. Fredy. 2012. Faktor Rasio C/N Awal dan Laju Aerasi Pada Proses Co-Composting Bagasse dan Bloting. Jurnal Teknologi Industri Pertanian Vol 22(3) : 173 - 179. 
Kementrian Kelautan dan Perikanan Republik Indonesai. 2016. Petunjuk Teknis Sarana Budidaya Minapadi. Direktorat Jendral Perikanan Budidaya. Direktorat Produksi dan Usaha Budidaya. Jakarta.

Lestari, S dan A. N. Bambang. 2017. Peran Mina Padi Dalam Rangka Mendukung Kesehatan Pangan dan Meningkatkan Kesejahteraan Masyarakat. Proceeding Biology Education Conference Vol 14(1): $70-74$.

Maulida, E. I. 2011. Pengaruh Vermikompos, Pupuk Kandang dan Pupuk Anorganik Terhadap Serapan Hara K dan Hasil Padi (Oryza sativa L) Beras Merah Di Lahan Sawah Kebakkramat Karanganyar. Skipsi. Universitas Sebelas Maret. Surakarta.

Sugiyanto dan S. A. Aziz. 2016. Beras Dan Tanaman Pangan Organik Lainnya. Bogor. IPB Press.

Sukroraharjo, A. 2018. Analisis Perubahan Penggunaan Lahan Di Kecamatan Gatak Kabupaten Sukoharjo Tahun 2013 dan 2017. Skripsi. Fakultas Geografi. Universitas Muhammadiyah Surakarta.

Suryani, A. S. 2014. Peran Bank Sampah Dalam Efektivitas Pengelolaan Sampah (Studi Kasus Bank Sampah Malang). Jurnal Aspirasi Vol 5(1): $71-84$.

Susanto, R. 2002. Pertanian Organik Menuju Pertanian Alternatif dan Berkelanjutan. Yogyakarta. Kanisius.

Zahroh, F., Kusrinah., S. M. Setyowati. 2018. Perbandingan Varietas Konsentrasi Pupuk Organik Cair dari Limbah Ikan Terhadap Pertumbuhan Tanaman Cabai Merah (Capsicum annum L.). Jurnal of Biology and Applied Biology Vol 1(1) : 50 - 57. 